\title{
ERRATUM
}

\section{Differential association of C-reactive protein with adiposity in men and women in an Aboriginal community in northeast Arnhem Land of Australia}

T Shemesh, KG Rowley, A Jenkins, J Brimblecombe, JD Best and K O’Dea

International Journal of Obesity (2007) 31, 564. doi:10.1038/sj.ijo.0803466; published online 5 September 2006

Correction to: International Journal of Obesity (2007) 31, 103-108. doi:10.1038/sj.ijo.0803350

Since the above publication the authors have noticed an error in the abstract of the paper. The word cholesterol incorrectly appeared in the Results section in the line above the definition for NCEP.

The correct definition of NCEP should read 'US National Cholesterol Education Program'.

The typesetters would like to apologise for this mistake.

\section{CORRIGENDUM}

\section{Association between symptoms of attention-deficit/ hyperactivity disorder and bulimic behaviors in a clinical sample of severely obese adolescents}

S Cortese, P Isnard, ML Frelut, G Michel, L Quantin, A Guedeney, B Falissard, E Acquaviva, B Dalla Bernardina and MC Mouren

International Journal of Obesity (2007) 31, 564. doi:10.1038/sj.ijo.0803467; published online 29 August 2006

Correction to: International Journal of Obesity (2007) 31, 340-346. doi:10.1038/sj.ijo.0803400

Since the publication of the above paper the authors have noticed an error in the corresponding authors email address. The correct email address for Dr P Isnard is shown below:

pascale.isnard@bch.aphp.fr

The authors would like to apologise for this mistake. 